\title{
The Impact of Divorce on Student's Academic Performance: The Case of Secondary School Students in Arba Minch Town
}

\author{
Abate Ashenafi Nigusse
}

\begin{abstract}
Divorce has psychological, economical and social impacts on the divorcees and their children. Children who experience their parents going through a divorce are often left susceptible to depression, acting out, and suffering problems of stress. When parents decide to divorce, their actions can affect their children's psychological wellbeings. Hence, the main objective of the present study was to assess the impact of divorce on student's academic performance in Arba Minch town secondary schools and to explore the conditions or situation that promote the academic performance of the students. Both quantitative and qualitative methods were employed to achieve the research objectives. The study participants were: 204 students from divorced parents, 4 school counselors and 10 divorced parents (student's parents). The students from divorced parents were taken using available sampling technique while divorced parents were conveniently taken and school counselor were purposively taken as a sample. The students were given questionnaire and face to face interviews were held with the divorced parents and the school counselors. Data from the quantitative survey were analyzed using percent, mean, standard deviation and t-test. The qualitative data were analyzed using direct quotation. The paired t-test comparison of group showed statistically significant mean difference in academic performance in students before and after their parental divorce. Students had higher academic performance before their parental divorce. However, there was no statistically significant mean difference in across gender. It was recommended that appropriate care and support to enhance the psychological wellbeing of the children, prioritization children during and after divorce, and co-parenting after divorce were forwarded to enhance academic performance of these students.
\end{abstract}

Key terms: Academic performance, Divorce, Impact, secondary school students

DOI: $10.7176 / \mathrm{JEP} / 12-28-04$

Publication date:October $31^{\text {st }} 2021$

\section{INTRODUCTION}

Education has been regarded as a vehicle for economic, social and political development. There has also been a growing commitment to education by government, individual communities and missionary bodies (Bettinger \& Slonim, 2007). This commitment on the part of government and other non-state actors has extended to ensure that students are properly groomed and tutored on how best to effectively manage by their parents in an ever-changing world. According to Adebayo (2008) to maintain academic expectations of the students is not only the concerns of colleges and universities; but also parents, teachers, and stakeholders are increasingly concerned with the academic performance of students as a measure of the effectiveness of higher institutions. Students are the most essential assets for any educational institution (Mushtaq \& Khan, 2012). Schools, colleges and universities have no worth without students.

Student's academic achievement plays an important role in producing the best quality graduates who would become great leaders and manpower for the country and responsible for the country's economic and social development (Magpily and Mercado, 2015). Academic achievement positively affects students in variety ways. For instance, productivity, intellectual skills, personal motivation effort on work, having prestige job, and career dynamism are positively related to academic success (Forla, Valcke and Cai, 2013).

Academic performance is what a student is capable of achieving when tested or examined on what he/she has been taught (Otu-Danquah, 2002). Many empirical studies have been carried out to determine factors affecting students' academic performance. Emeke (1984) pointed to a combination of personal and institutional factors which are capable of influencing students' academic performance. He explained that the personal factors related to the individual's intelligence, knowledge and ability while institutional factors include family or parental influences, societal influences and school related factors such as student-teacher rapport and teacher related factors like their accommodation and living conditions.

Among institutional factors that affects academic performance of students; family/Parents are important in providing environmental, social and economic factors, which have powerful effects on pupils' academic lives. It has been documented that parents' stability lives, readiness to contact teachers about their children's improvement is possibly the first step to becoming involved in education (Serkalem, 2006).

Divorce has become commonplace in today's society, however the impact divorce has on children is not clearly profound. Divorce changes a considerable number of things in the child's life including possible changes in residence, relationship with parents, change in socio-economic standing and exposure to martial conflict (Amato and Anthony, 2014). With all these change in child's life it is not surprising that substantial impact on the development and academic performance of the students. Academics are one of the most important aspects of a 
student's life. With good grades, students are able to get into colleges and universities, and allow them to earn degrees in order to obtain jobs that they want.

Different Research reports indicated parental divorce was highly related with the negative effect of academic performance of the children (Fagan and Churchill, 2012; Berlin, 2004; Aemero, 2013). For example, Berlin (2004) examined that Children who grow up in an intact, two-parent family with both biological parents participated in school, discussed about children education, the children's subject issues and about their friends more than children who grow up in a single-parent family.

However, other researchers, (Biblarz and Gottainer, 2000; Amato and Keith, 1991; Bartholomew and Kwadwo, 2015) reported there was no statistically significant difference in academic performance between children in divorced and non-divorced parents. Amato and Keith (1991) demonstrated that children from divorced families show similar levels of educational and occupational attainment compared to those from two-parent families. They conclude that parental divorce was not a predictor of failure of academic performance of students.

In the aforementioned research review, it seems that there were inconsistent results about the relationship between the study variables and present researcher was interested to investigate the issue further. Therefore, the objective of the present study was to examine the academic performance of student from divorced parents. These were done by comparing the student's performance before and after their parental divorce. Accordingly the study was designed to answer the following basic questions;

1. Is there a statistically significant academic performance difference among students before and after their parental divorce?

2. Is there a statistically significant gender difference in academic performance of students in divorced parents?

\section{Research design}

This study was used descriptive survey design combining both qualitative and quantitative (Mixed) research method. Descriptive survey is appropriate to describe the existing phenomena: including human behavior. According to Mugenda and Mugenda (1999) the survey design is the best method available to social scientists who are interested in collecting original data for the purposes of describing a population which is too large to observe directly. Also the study was investigated the impact of divorce on the student's academic performance. Both quantitative and qualitative methods were implemented in embedded or in sequential way. However, the two strands have been conducted separately during data collection and analysis period; however it was mixed during overall interpretation of the study. The researcher triangulated the results from the two strands in order to draw a corroborated conclusion about the research problem.

\section{Population}

Population, in the essence of research, refers to the group of people or objects consisting of the sampling units relevant to the research question (Grove et al., 2013:351). The population of the study was those students whose parents are divorced in secondary schools in Arba Minch city.

\section{Participants of the Study}

The subjects investigated in this study were encompass students from the divorced parents. To supplement the students' data; school counselors \& student's parent were also participated. There was no complied data regarding students of divorced parents in secondary schools. To this regard, the lists of students of divorced parents were obtained from Arba Minch town first instance court. They had adequately organized data's regarding adoption, divorce, custody, maintenance, and other children issues since 2012. Moreover, the last 3 years divorcee cases and their children profiles were well managed: including their address, each child profile (age, school, grade, custody parent, and other necessary information's). Therefore, the researcher was used the last three years (2015/162017/18) recorded data's to investigate the impact of parental divorce on children's academic performance.

The social workers custody investigation document indicated that $325 \mathrm{high}$ school students were separated from one parents due to divorce cases in the last three years. Among 325 students, 184 were female and 141 male students respectively. However, from all secondary schools only 204 students were founded by the researcher with collaboration of social workers, school counselors and homeroom teachers.

To get the necessary information as the main subjects of the study, 204 students from divorced parents were taken through availability sampling. Four school counselors \& 10 divorced parents were conveniently sampled. The students were given questionnaire and semi structured interview were held with divorced parents \& school counselors.

\section{Instrument for Data Collection}

Academic performance was measured by tests, exams, and classroom activities. Still it was used as the most widespread measure of academic performance (Magpily and Mercado, 2015). Students average scores before and 
after their parents divorced were used to measure the impacts of divorce on the student's academic performance. Average grade points (AGps) were collected by assessing official school records to compare with their academic performance before and after parental divorce. Besides to this, a semi-structured interview was also employed to gather qualitative data from counselors \& divorced parents to verify students' results and to respond research question number three. Specifically, the face-to-face interview was used.

\section{Data Analysis}

The students' scores collected from the record office of schools were analyzed using quantitative method. The data were screened, coded; enter into computer, and re-screened, to ascertain the accuracy of the data.

The researchers used the SPSS version 20 to run paired (correlated) t-test to analyze the differences in academic performance of students before and after parental divorce. This was done at a significance level of $p$ $<.05$. Where us, Independent sample t-test was used to distinguish the academic results between male and female students in divorced parents. With regard to the analysis of the semi-structured interview data, it was used to clarify the quantitative data and to answer number 3 research questions. Specifically, a direct quotation was used to support or clarify the quantitative data. Serial numbers were assigned to the interview transcripts so as to attribute statements to the parents, judges and the school counselors.

\section{Results}

This section presents the results of the study in terms of the basic research questions that deals the parental divorce and gender as independent variable and academic achievement as dependent variable.

The data were collected from 204 available secondary school students of divorced parents and the data was entered in to SPSS version 20 software for the statistical output and then the responses were analyzed with the means of descriptive methods of data analysis such as tables, charts, frequency distributions, percentages, mean and t-test were used. Whereas, the interview made with the key informants from divorced parents $\&$ counselors were recorded and analyzed through qualitative methods of data analysis.

Table1: Demographic Characteristics of Respondents

\begin{tabular}{lccccc}
\hline & Age & & & \\
& $11-13$ & $14-17$ & $18-21$ & 3 & Total \\
\hline Male & 18 & 59 & 15 & 21 & 95 \\
Female & 28 & 55 & 24 & 5 & 109 \\
\hline Total & 46 & 114 & 39 & 204
\end{tabular}

Source: Researcher survey data, 2019

As shown in Table 1, 204 high school students of divorced parents were participated in the study. Among these, 95(46.6\%) of the participants were male and the remaining 109(53.4\%) were females.

Regarding ages of respondents, the above Table shows that $16(7.84 \%)$ of students of divorced parents were between 11-13 years, $114(55.88 \%)$ of students were between the age of $14-17$, while $69(33.83 \%)$ were between the age of 18-21 and 5(2.5) were greater than the age of 21 . From this we can understand that the majority of the respondents are found in middle adolescents of developmental stage.

The demographic information also asked respondents with whom they are living. The finding from the data analysis is shown in the pie-chart that follows;

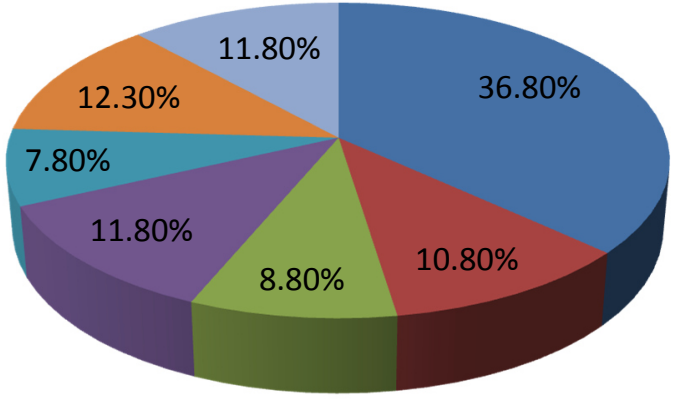

Only with mother

Only with father

Mother and stepfather

Father and stepmother

Only with himself

With grand parents

with relatives and others

Fig 1: Students that are living with after their parental divorce 
Figure 2 show that current living condition of student of divorced parents. The data uncovered that majority of students $75(36.8 \%)$ were living only with their mothers, $25(12.3 \%)$ were with grandparents, $22(10.8 \%)$ were with fathers, $18(8.8 \%)$ were with their mothers and step fathers, $24(11.8 \%)$ were with their fathers and step mothers, $24(11.8 \%)$ were with relatives and others, and 16(7.8\%) were living independently.

\section{Academic Performance}

The objective of this study was to investigate differences in academic performance of students before and after parental divorce. Hence, to measure the academic performance, one year average score of students before parental divorce and one year average score of students after divorce were taken from school records.

Table 2: Academic Performance of the Students before Parental Divorce

\begin{tabular}{lllll}
\hline No & Student's scores & Frequency & Percent & Cumulative percentage \\
\hline 1 & $41-45$ & 2 & $1.00 \%$ & $1.00 \%$ \\
2 & $46-50$ & 11 & $5.40 \%$ & $6.40 \%$ \\
3 & $51-55$ & 28 & $13.74 \%$ & $20.14 \%$ \\
4 & $56-60$ & 28 & $13.74 \%$ & $33.88 \%$ \\
5 & $61-65$ & 35 & $17.16 \%$ & $51.08 \%$ \\
6 & $66-70$ & 34 & $16.67 \%$ & $67.71 \%$ \\
7 & $71-75$ & 31 & $15.20 \%$ & $82.91 \%$ \\
8 & $76-80$ & 24 & $11.80 \%$ & $94.71 \%$ \\
9 & $81-85$ & 11 & $5.40 \%$ & $100 \%$ \\
\hline
\end{tabular}

Source: Researcher survey data, 2019

Regarding academic performance of students before parental divorce, figure 3 shows that two students were scored between $41-45 \%$, eleven students were between $45-50 \%$,twenty eight(28) students were scored between $51-55 \%$, similarly twenty eight (28) students were between 56-60\%, thirty five students were scored between 61 $65 \%$, thirty four students were between $66-70 \%$, thirty one students were between $71-75 \%$, twenty four students were between $76-80 \%$ and eleven students were scored between $81-85$ percent.

Moreover, the figure 3 indicates that $191(93.6 \%$ ) of students had academically performed above $50 \%$ and $13(6.4 \%)$ students were below $50 \%$ prior to divorces. In line with this result (Emeke,1984) stated that good relationship with their parents and parent's involvement in their child's education are most important predictor of student academic success. Moreover, he suggested that stability of family structure impacts both the average grade points and attendance of high school students.

\section{Table 3: Academic Performance of the Students After Parental Divorce}

\begin{tabular}{lllll}
\hline No & Student's scores & Frequency & Percent & Cumulative percentage \\
\hline 1 & $41-45$ & 12 & $5.88 \%$ & $5.88 \%$ \\
2 & $46-50$ & 22 & $10.780 \%$ & $16.66 \%$ \\
3 & $51-55$ & 38 & $18.62 \%$ & $35.28 \%$ \\
4 & $56-60$ & 38 & $18.62 \%$ & $53.90 \%$ \\
5 & $61-65$ & 26 & $12.74 \%$ & $66.64 \%$ \\
6 & $66-70$ & 32 & $15.68 \%$ & $82.32 \%$ \\
7 & $71-75$ & 19 & $9.310 \%$ & $91.63 \%$ \\
8 & $76-80$ & 12 & $5.88 \%$ & $97.51 \%$ \\
9 & $81-85$ & 5 & $2.49 \%$ & $100 \%$ \\
\hline
\end{tabular}

Source: Researcher survey data, 2019

Figure 4 indicates the academic performance of wards of divorced parents. The figure indicates twelve students were scored between $41-45 \%$, twenty two students were between $45-50 \%$, thirty eight students were scored between $51-55 \%$, similarly thirty eight students were between $56-60 \%$, twenty six students were between $61-65 \%$, thirty two students were between $66-70 \%$, ninety were scored between $71-75$, while twenty students were between 76-80 and five students were scored between $81-85 \%$ after parental divorce. The figure further shows that $34(16.7 \%)$ students were scored below 50 percent and 110(54\%) of students' academic performance are below 60 percent after their parents' divorce.

To check whether there is statistically significant difference between academic performance of students before and after parental divorce, paired t-test was computed. Significance level of $\mathrm{p}<0.05$ 
Table 7: Paired Samples Test

\begin{tabular}{|l|l|l|l|l|l|}
\hline Domains & Marital Status & Mean (M) & $\begin{array}{l}\text { Standard } \\
\text { deviation (SD) }\end{array}$ & t-value & P-value \\
\hline $\begin{array}{l}\text { Academic performance } \\
\text { students }\end{array}$ & BPD & 5.43 & 1.965 & 10.257 & .000 \\
& APD & 4.50 & 2.016 & & \\
\hline
\end{tabular}

$*=P<0.05, d f=203$

$B P D$ refers one year average score of students before parents' divorce

$A P D$ refers one year average score of students after parents' divorce

The paired (Correlated) t-test result with respect to academic performance revealed that before their parental divorce students had mean value of 5.43 with standard deviation of 1.965 while after their parental divorce the students had mean value of 4.50 with standard deviation of 2.016 . The obtained t-value is 10.257 which is significant at $p<0.05$ level of significance. This indicates that there was statistically significant mean difference in academic performance in students before and after their parental divorce. Therefore, students had higher academic performance before their parental divorce than after divorce.

In response to the question, how would you rate the academic performance of your child since you became a divorced parent? Some of the parents gave several opinions:

A parent said, "The academic performances of my children are going down since the divorce. In fact, he is absent minded both at home and in school. He is academically weak. (DP1).

Another parent remarked, "It has gone low. She has been repeated twice due to the change in family structure or pattern and movement after the divorce. The level of her academic performance is average after the family disintegrated. "(DP2)

It becomes clear that independently of socio-economic status and other predictor variables including endogenous variables (covariates), the academic performance of the affected students was largely dependent on divorce. The variability in the academic performance of the affected students was largely explained by the influence of divorce. Thus, divorce is highly predictive of poor academic performance of the affected children.

The Effect of Gender on Students' Academic Performance

An independence sample t-test was conducted to see whether there exists significance differences in student's academic performance across sex before/after their parents had divorced.

Table 8: Independent Samples T-test Analysis for Differences in Academic Performance Before Parental Divorce across Gender

\begin{tabular}{lllllll}
\hline Domain & Sex & Mean(M) & $\begin{array}{l}\text { Standard } \\
\text { deviation(SD) }\end{array}$ & t-value & Df & $\begin{array}{l}\text { Sig } \\
\text { tailed }\end{array}$ \\
\hline APBPD & Male & 5.29. & 1.945 & & & \\
& Female & 5.54 & 1.984 & -.893 & 202 & .373 \\
\hline
\end{tabular}

$*=P<0.05, d f=202$

Note: sex code: male $=1$, female $=2$

$A P B P D$ refers to academic performance of students before parental divorce

The independent t-test result with respect to academic performance revealed that male had mean value of 5.29 with standard deviation of 1.945 while females had mean value of 5.54 with standard deviation of 1.984 . The obtained t-value is -.893 which is not significant at $\mathrm{p}<.05$ level of significance. This implies $-.0893>.05$, this means both male and female students had slightly similar academic performance before their parental divorce. In other word, there were no statistically significant mean differences in academic performance between male and female students before their parental divorce.

Table 9: Independent Samples T-test Analysis for Differences in Academic Performance After Parental Divorce across Gender

\begin{tabular}{lllllll}
\hline Domain & Sex & Mean(M) & $\begin{array}{l}\text { Standard } \\
\text { deviation(SD) }\end{array}$ & t-value & Df & $\begin{array}{l}\text { Sig } \\
\text { tailed }\end{array}$ \\
\hline APBPD & Male & 4.26 & 2.028 & & & \\
& Female & 4.71 & 1.992 & -1.527 & 202 & .117 \\
\hline
\end{tabular}

$*=P<0.05, d f=202$

Note: sex code: male $=1$, female $=2$

APAPD refers to academic performance of students after their parental divorce

The independent t-test result with respect to academic performance revealed that male had mean value of 
4.26 with standard deviation of 2.028 while females had mean value of 4.71 with standard deviation of 1.992 .The obtained t-value is -1.527 which is not significant at $p<.05$ level of significance. In other word, $0.117>.05$, there was no statistically significant mean differences in academic performance between male and female students. This implies difference in sex group creates no significant mean difference in academic performance within group of students from divorced families.

\section{Discussion}

In this section, the findings of the present investigation are discussed in the light of findings of previous studies and possible explanations.

\section{Students' Academic Performance before and after Parental Divorce}

One of the objectives of the present study was to investigate differences in academic performance of students before and after parental divorce. Thus, in order to determine the difference of academic performance of students before and after their parental divorce Paired Samples Test (t-test) was computed.

The result indicates there was statistically significant mean difference in academic performance in students before and after their parental divorce. The paired (Correlated) t-test result with respect to academic performance revealed that before their parental divorce students had mean value of 5.43 with standard deviation of 1.965 while after their parental divorce the students had mean value of 4.50 with standard deviation of 2.016. The obtained tvalue is 10.257 , which is significant difference at $p<0.05$ level of significance. This indicates that student's academic performance was higher before parental divorce than after parental divorce as measured annual average score of students.

It becomes clear that independently of socio-economic status and other predictor variables including endogenous variables (covariates), the academic performance of the affected students was largely dependent on divorce. The variability in the academic performance of the affected students was largely explained by the influence of divorce. Thus, divorce is highly predictive of poor academic performance of the affected children. This result was consistent with a study (Bartholomew and Kwadwo, 2015) who found that there was statistically significant difference in academic performance before and after parental divorce high school students. They explained that students who come from divorced families would not be able to concentrate in class because divorce affects the psyche, emotion and behavior of children. This could eventually lead to disinterest in school and poor academic performance. Similarly (Frum, 1996; Wolchick, 2002; and Rodgers \& Rose, 2001) have observed that children from divorced families are impacted negatively when it comes to school performance. In another study (Aemero, 2013) examined that statistically significant difference in academic achievement in students of intact and divorced family, which favor of students from intact families.

\section{Differences in Academic Performance across Gender}

The other objective of the present study was to distinguish the academic results between male and female students in divorced parents. Thus, in order to distinguish the academic results between male and female students in divorced parent's independent t-test was computed.

The result indicates that there was no statistically significant mean difference in academic performance between male and female students. This study is some extent inconsistent with the study of Aemero (2013), who found that academic achievement of students between the sexes is statistically significant mean difference in divorced parents. His research results indicated that males were received a substantially higher mean achievement than females. Similarly, Serkalem (2006) stated that girls in divorced families' shows increased signs of depression, decline academic performance, and accumulate a higher percentage of drop-out rates compared to those boy students.

Parenting practice, socialization, roles and expectations differ according to the sex of the child.

The society's discriminatory practices on women prevent them from attaining equal educational level with men in the past years (Tilson and Larsen, 2000). The researcher believes that the finding of this study differs from that of other researches was findings that mostly come out before six years. In recent years special attention was given to female education. The Ethiopian government, non- governmental organization, religious institutions, teachers, parents and other concerning bodies have been working together to address the problem of female students and to improve their academic performance. The government has been enforcing/implementing the gender equality in different states of the country.

Tsigereda (2010) has stated that since the practice of affirmative action in Ethiopia, there have been imperative changes in number of female students in academic performance. Providing additional support to female students can cope up with their academic challenges and minimized the performance gaps between male and female students. RFC (2000) also ratified "all actions concerning children undertaken by public and private welfare institutions, courts of law, administrative authorities or legislative bodies the primary consideration shall be the best interest of the child". Furthermore, Child justice project was established in recent years to mainly ensure all 
action and decision of authorities, courts and legal bodies in child cases shall be made with regard to the best interest of the child.

\section{Conclusion}

$\checkmark$ Academic performance of students from divorced families was high prior to the divorce; while academic performance of students from divorced families dropped after the divorce. Therefore, parental divorce is highly predictive of poor academic performance of the affected students.

$\checkmark$ Parental divorce develops low self-confidence, feeling loneliness, inferiority, depression, fear, stress and disturbs the attention of the students in classroom. This factor exposes the affected students to low educational aspirations, which eventually negatively influences their academic performance.

$\checkmark \quad$ The result indicates that there was no statistically significant mean difference in academic performance between male and female students. This may be due to the practice of affirmative action, effective implementation gender equality, gradual attitude change of the society, special attention from the GO, NGO and others.

$\checkmark$ Parent's proper communication during the divorce, encouraging the students' self-esteem, providing appropriate care and support to enhance the psychological wellbeing of these children. Children prioritization during and after divorce were suggested by interviewees as solution to enhance academic performance of these students.

\section{Recommendations}

Based on the above conclusions, the following are recommended:

$\checkmark$ This study indicates parental divorce develops low self-confidence, feeling loneliness, inferiority, depression, fear, stress, develop hopeless, high absents from classroom and disturbs the attention of the students in classroom. This factor exposes the affected students to low educational aspirations, which eventually negatively influences on their academic performance. Therefore, the Arba Minch town women and children affair, Faith-Based Organizations (FBOs) or churches, Non-Governmental Organizations (NGOs) and Civil Society Organizations (CSOs), traditional and public welfare as well as media institutions in the town should carry out public education to sensitize the people in the area on the menace of divorce.

$\checkmark$ The researcher strongly recommends that children priorities need to be placed at the frontline during the divorce process as they are adversely affected by divorce..

$\checkmark \quad$ All schools should set up guidance and counseling offices facilitated by professionals to counsel students whose parents were divorced. This will help to care of students with emotional needs that they wish to share in confidence about their home frustration, family breakup, educational aspiration, psychological disturbance and other personal issues.

$\checkmark \quad$ The school principals, homeroom teachers and school counselors should identify students from divorced parents and make special attention to look their problems and establish support system. The supporting system may be providing counseling services, material supports, communicating with their parents/guardians, referring to concerned bodies.

$\checkmark \quad$ Finally, a follow up study should be done to determine if the findings of this study can be verified by another similar study. Besides, there should be an extensive research on the impact of divorce on children's psychological and cognitive development. This is because further research could provide new insight and strategies for improving their development as well as their lives in general.

\section{REFERANCE}

Adebayo, B. (2008).Cognitive and non-cognitive factors affecting the academic performance and retention of conditionally admitted freshmen. Journal of college admission www.nacanet.org

Aemero A. C. (2013). Assessing children academic achievement as correlates with parents Marital status: The case of junior high school students in Addis Ababa. PhD Dissertation.Addis Ababa University, Ethiopia

Amato, P. R. \& Anthony, C. J. (2014). Estimating the Effects of Parental Divorce and Death with Fixed Effects Models. Journal Of Marriage \& Family, 76(2), 370-386.doi:10.111/jomf.12100

Amato. P.R and Keith, B. (1991a). Separation from parent during childhood and adult socio-economic attainment. Social forces, 70 187-206

Bartholomew, A., and Kwadwo, O. A,(2015).Effects of divorce on the academic performance of some selected public senior high school students, International journal of multidisciplinary and research and development Vol: 2, no: 10, 375-38

Berlin, G. (2004). The effects of marriage and divorce on families and children. MD

Bettinger E; Slonim R 2007. Patience among children, Journal of Public Economics, 91(1-2): 343-363

Biblarz T.J and Gottainer,G. (2000).Family structure and children success: A composition of widowed and 
divorced single-mother families. Journal of Marriage and the Family, 62, 533-548

Emeke, E.A (1984). Relationship between personal problems and study habits. Journals of Applied Psychology, 3,113- 129.

Fagan P.F. and Churchill A. (2012). The Effects of Divorce on Children, Marriage and religionresearch institute, January 11, 2012

Federal Negarit Gazetta of the Federal Democratic Republic of Ethiopia, (2000), Revised FamilyCode (RFC) Proclamation of 2000, Addis Ababa.

Forla, J., Valcke,M.,andCai, Y.(2013).Academic self-efficacy and academic self-concept; reconsidering structural relationships.Faculty of psychology and educational science. Ghent University y, Belgium.

Frum, David (1996, Feb.). The social cost of single parenthood. Reader's Digest, Canadian Edition, 148 (886), 29-30.

Magpilay, M.,and Mercado, J. (2015).Non-cognitive factors affecting the academic performance of fourth year college students of a private college in manila. Athens journal of education,2(3),manila, Philippines

Mugenda, O. M. \& Mugenda, A. G. (1999).Research Methods: Quantitative and Qualitative Approaches. Nairobi: Acts Press.

Mushtaq, I.,and Khan,S. N. (2012).Factors Affecting students academic performance Global journal of management and business Research,12(9),1.

Otu-Danquah, M. (2000). Gender differences in academic achievements in English, Science and Mathematics of senior secondary school students in the Cape Coast Municipality, Ghana. University of Cape Coast. Unpublished dissertation.

Roghers K. B. and Rose, H .A. (2001). Personal, Family and school factor of related to adolescents' academic performance: A comparison by family structure. Marriage and family Review, 33(4) 47-61.

Serkalem B. (2006), Divorce: its causes and impacts on the lives of divorced women and their children, A comparative study between divorced and intact families, Addis Ababa

Tilsen D. and Larson U. (2000), Divorce in Ethiopia: The Impact of Early Marriage and Childlessness. Journal of biosocial science, 32, pp 355-372

Wolchik, S. (2000). Preventive interactions for children of divorce. Journal of American Medical association, 288(15), 1874-8 